\title{
Relational Cohesion Model of Organizational Commitment
}

\author{
Jeongkoo Yoon \\ Ewha Womans University
}

\author{
Edward J. Lawler \\ Cornell University
}

Relational Perspectives in Organizational Studies edited by Olivia Kyriakidou \& Mustafa F. Özbilgin 


\section{Introduction}

This chapter reviews the research program of relational cohesion theory (RCT) (Lawler \& Yoon, 1993, 1996, 1998; Lawler et al., 2000; Thye et al., 2002) and uses it to develop a model of organizational commitment. Broadly, relational cohesion theory (RCT) has attempted to understand conditions and processes that promote an expressive relation in social exchange; an expressive relation is indicated by relational cohesion, that is, the degree to which exchange partners perceive their relationship as a unifying object having its own value. The research program argues that such relational cohesion is a proximal cause of various forms of behavioral commitment in a group setting, for example stay behavior, gift-giving and investment.

In this chapter, we develop a model of organizational commitment through the following three steps: First, we review the program of relational cohesion theory (RCT) and establish the key theoretical concepts and theorems through which it explains how instrumentally motivated actors in exchange relations develop an expressive relation. Second, we apply the concepts and theorems to derive a 'relational-cohesion model' of organizational commitment. Third, we examine the heuristic value of the new model by deriving predictions with respect to several organizational phenomena to which conventional organizational commitment theories may not have paid sufficient attention. The role of emotions is highlighted and our purpose is to theorize the interrelationships of instrumental, affective and normative forms of organizational commitment.

The original idea of commitment in RCT is inspired by Parsons's (1951) seminal distinction between person-to-collective attachment and interpersonal attachment (Lawler, 1992a). Building upon Parson's distinction, RCT defines commitment as an attachment of an 
individual to a collective entity such as a relationship, group, organization, community or society (see also Kanter, 1968). A leading social identity theorist, Hogg (1992), suggests a similar distinction by indicating that individuals' identification with social categories constitutes the minimal condition of a group, and this cannot be reduced to interpersonal attachments; psychological groups emerge through individuals' attachment to (or identification with) a group even in the absence of interpersonal relationships among its members (also see Hogg \& Turner, 1985). On this view, an individual's attachment to a collective can be applied broadly to groups, organizations, communities or societies. To date, RCT has focused on relational and group attachments, and this chapter applies RCT to organizational commitment.

One of the key features that differentiate RCT from other exchange theories is its emphasis on emotions in organizing human activities and transactions. Most commitment models derived from exchange theories have neglected the potential significance of an expressive orientation. For instance one of the most well-developed commitment theories in the exchange theory literature, Rusbult's (1980,1983; Rusbult \& Buunk, 1993; Rusbult et al., 1998) investment model, defines commitment as a motivation to continue or remain in a relationship, a state that is in turn predicted by three instrumental indicators (investment, satisfaction and the quality of alternatives). Adopting exchange theory theorems (Homans, 1961; Thibaut \& Kelley, 1959), the investment model indicates that satisfaction with a relationship is a function of rewards minus costs compared with a general expectation. Similar to sunk costs or side bets (Becker, 1960), an investment is the amount of resources put into a relationship that could not be retrieved even if the relationship ended; and the quality of alternatives is the totality of benefits of a current relationship relative to those obtainable from alternative relationships. Another exchange theorybased commitment model is provided by Cook and Emerson's (1978) study, which also adopts 
an instrumental orientation to commitment. They define commitment as stay behaviour that is fostered by a sense of predictability (uncertainty reduction) regarding one's partner. A series of successful transactions between partners in a network help them to know each other better, develop a common set of expectations, and thereby increase the costs of initiating new transactions with alternative partners. Reduced transaction costs and predictability in turn encourage the exchange partners to remain in the established relation. Extending this theory, Kollock (1994) theorizes commitment more explicitly as a behavioral strategy designed to reduce uncertainty when the quality of products is unknown.

In contrast to these instrumental approaches, RCT advocates viewing commitment as an expression of emotional attachment. Treating affective attachment as one of the key organizing principles of human behavior, RCT sheds light on a fundamental aspect of commitment behavior that has often been neglected in exchange theories. To understand the affective nature of a committed relationship, RCT highlights several structural conditions under which an instrumental exchange transforms into an expressive one, as well as emotional processes through which exchange partners perceive a relationship as valuable in itself, that is, as an expressive object. ${ }^{1}$ In the sections that follow, we review relevant exchange theories that provide RCT with its theoretical background.

\section{Theoretical background}

Social exchange is a ubiquitous phenomenon. It occurs in neighbors' exchanges of favors, peers' exchanges of assistance, friends' exchanges of gifts, scholars' exchanges of research ideas, and even spouses or partners' exchanges of affection. A common principle 
underlying these exchanges is reciprocal obligation (Gouldner, 1960; Blau, 1964). If one asks a friend for a favor, this entails a general expectation of future return. Reciprocal obligations differentiate social exchange from economic transactions. Each economic transaction is discrete and independent, whereas the reciprocity principle in social exchange entails repetition and obligations for future interaction. If one buys a house from a seller, the transaction is consummated by paying the exact price for the house. The transaction does not require other obligations or interactions in the future. In contrast, commodities and services in social exchange do not have exact prices. Instead, consummating a social exchange necessarily builds up feelings of personal obligation, gratitude and trust among partners, all of which lay a foundation for social solidarity and micro social order even without binding contracts.

Social exchange theory emphasizes the structural context of transactions in which two or more actors seek to arrive at a satisfactory exchange of benefits. The context of a relationship is structured by repeated opportunities for social transactions among the same actors (Emerson, 1981). This structure constitutes the building block of a micro social order that is manifest in stable frequencies of interaction among a set of exchange partners (Cook \& Emerson, 1978; Blau, 1977). Emerson's $(1972,1981)$ exchange theory analyzes enduring exchange relations in terms of power and dependence. From Emerson's power-dependence perspective (Emerson, 1972), A's power capability in exchange relation to B $(P a b)$ is determined by B's dependence on $\mathrm{A}(\mathrm{Dba})$, and B's power capability in relation to A $(\mathrm{Pba})$ is determined by A's dependence on B $(D a b)$. The dependence of A on B $(D a b=P b a)$ is, in turn, a joint function varying (1) directly with the value of the outcomes or rewards controlled by B (Vab) and (2) inversely with the availability and value of A's alternative sources. 
Elaborating Emerson's power-dependence theory, Lawler and others advance a non-zero sum approach to power dependence (Bacharach \& Lawler, 1981; Lawler, 1992b; Lawler \& Ford, 1993). A zero-sum approach indicates an inverse relation between individuals’ power capabilities; an increase in A's power by definition implies a decrease in B's power. As such, the focus in a zero-sum conception is on the differentiating, coercive and divisive effects of a power capability, ignoring the collaborative nature of power. A non-zero sum conception suggests an important, but neglected feature of power dynamics - namely, that the total or average power in a relation can change intentionally or unintentionally. For instance dependence on each other (total dependence) can increase or decrease simultaneously by mutually changing the value of the outcomes or the alternative outcome sources in the same direction. Emerson (1972) identifies this as a 'cohesion effect' of mutual power, and Thibaut and Kelley's (1959) notion of mutualfate control also taps this aspect of power. Distinguishing total and relative power as two independent dimensions of power, Lawler and Yoon (1996) indicate that a structurally cohesive relationship occurs under higher total power and lower relative (unequal) power. In their research, they found that structural cohesion in exchange relations promotes relational cohesion and behavioral commitment to the relation as a social unit.

Among the standard exchange theory explanations for relationship development is that certain power-dependence conditions in exchange relations promote frequent exchange with the same actors (Emerson, 1972; Lawler et al., 2000). When actors repeatedly exchange resources, they learn more about one another, find each other more predictable, and infer that they have similar orientations to the exchange task. Predictability, expectation confirmation and reduced transaction costs are key benefits of staying with the same actor (Cook \& Emerson, 1978; Emerson, 1981; Molm, 1994; Molm \& Cook, 1995). Research in cognitive psychology explains 
this in terms of risk aversion, that is, the propensity for individuals to avoid unpredictable or uncertain decision contexts (Tversky \& Kahneman, 1974). This same theme emerges in a variety of other commitment explanations, ranging from those centered on trust (Pruitt \& Kimmel, 1977) or relation-specific assets (Williamson, 1981) to those dealing with embeddedness within larger social units (Granovetter, 1985). Taken as a whole, these theories generally agree that reduced uncertainty sets the focal relation or group apart from others and inclines actors to perceive greater instrumental value in focal relations or groups.

Relational cohesion theory (RCT) questions this instrumental explanation of commitment in exchange theories. First, the instrumental foundation assumed by exchange theorists explains only one class or form of commitment, that is, instrumental commitment in Kanter's (1968) terms. This instrumental explanation is analogous to an explanation of transactions in a grand spot market in which ties do form to realize instrumental incentives embedded in the relations. A problem is that it does not explain why actors remain in such relations in the face of better alternatives, competitive bidding and changing incentives in the environment (Frank, 1988, 1993; Lawler et al., 2000). Rational choice theories and network exchange theories have also attempted to resolve the same problem by embedding a variety of incentive configurations in social structures. They assume that once optimal incentive structures for multiple actors are configured and imposed exogenously on a given social relation or structure, actors would actualize them. The identities of those who carry the incentive structure do not matter because neither barriers nor coordination problems are assumed in realizing potential incentive structures (Hardin, 1968; Hechter, 1987; Macy, 1993; Yamagishi, 1995). In brief, the instrumental explanations proffered by both rational choice and network exchange theories treat human beings as cognitive calculators and their actions as reflections of the incentives embedded in structures. 
RCT proposes that social structures or relations have both enabling and constraining effects on actors (see also Giddens, 1984); this aspect of social structure or relations provides actors with opportunities to experience certain emotions and cognitions; they actively construct and reconstruct reality based on these emotional and cognitive experiences. Like instrumental explanations, RCT treats social structures or relations as exogenous conditions. However RCT expands the instrumentally oriented approaches by emphasizing the process of emotional experience triggered by human action and social interaction. The theory assumes that human beings as voluntary agents interpret a given structure and use the experience of emotions in actively interpreting and reconstructing their own experience. This emphasis of RCT on emotions, cognition and agency in explaining commitment dovetails with Coleman's (1990) framework and Collins's (1981) interaction ritual chains. Coleman advocates the use of microorder theories for explicating how human beings exploit or explore given structures and re-create new structures through rationally driven human agency. Collins (1981) also explains how actors experience emotional uplift through encounters and how these emotions help actors create solidarity. In sum, RCT focuses on emotional experiences and cognitive work and the role they play in transforming a purely instrumental relationship into an expressive one.

\section{Relational cohesion theory}

A core idea in RCT is that social exchange has emotional as well as instrumental effects on actors and, if these are attributed to social units, then social units take on expressive value or intrinsic worth. Persons develop stronger ties to groups that are perceived as sources of positive feeling or emotion and weaker ties to those perceived as sources of negative feeling or emotion 
(Lawler, 1992a). These ties are instrumental to the degree that they reflect the benefits of mutually satisfactory exchange; they are expressive to the degree that the social unit becomes a distinct object of affective attachment. In this manner, RCT shows how emotions transform an instrumental relation into an affective object (Lawler \& Yoon, 1996, 1998).

The theory contains three foundational ideas (Thye et al., 2002). First, exchange structures shape who is likely to interact and exchange with whom, by providing incentives for actors to exchange with some potential partners and not others (Skvoretz \& Lovaglia, 1995). The same actors are likely to exchange with each other across time under fixed structural exchange conditions. Second, successful exchange efforts produce an emotional buzz, that is, mild, positive feelings; failure to accomplish exchange generates mild negative feelings (Lawler \& Yoon, 1996, 1998). The emotions of concern here are involuntary and internal events that simply 'happen to people' (Hochschild, 1983). Parallel to this emotional process, successful exchanges also reduce uncertainties in the relation and strengthen the boundary between focal and alternative relations; this uncertainty reduction reduces transaction costs in the focal relation and builds a foundation of trust (Williamson, 1981; Kollock, 1994). Third, actors are motivated to understand the sources of these feelings because they want to reproduce good feelings and avoid bad feelings in the future. This stimulates cognitive work in which they are likely to identify social units - exchange relations or groups - in explaining their emotions. The emerging boundary between focal actors delineated by uncertainty reduction facilitates the actors' attributions by making the sources of positive emotions salient (Lawler, 1992a). Thus the relation to the group becomes an object of attachment by virtue of being perceived as a source of positive individual feelings. Cohesion and commitment are a result of this. 
Based on the above discussion, Figure 8.1 shows the exogenous, endogenous and dependent variables in the theoretical model. The exogenous conditions are the structural relations of power dependence or interdependence among the actors (Emerson, 1981; Molm, 1994). Power is defined in terms of dependence, and as a structural capability distinct from both its use (tactics or strategies) and the actual or realized power resulting in the division of pay-offs (Emerson, 1972; Bacharach \& Lawler, 1981; Lawler, 1992b; Molm, 1990). Given a group of multiple actors, each actor's dependence on the group is equal to the maximum benefit from the focal group compared with the maximum benefit from an alternative group. The total dependence in the group refers to the average of each member's individual dependence on the group. Dependence equality or inequality refers to relative differences in degrees of dependence on the group among its members.

RCT predicts that greater total dependence and equal dependence will produce more frequent and successful exchange in the focal group. Higher total dependence reduces the opportunity costs of opting for an alternative group; it also gives members greater adaptive flexibility in negotiations and more room for misperception or miscalculation. This is because under higher dependence there is a wider range of agreements that meet a 'sufficiency' criterion, that is, provide each actor with more than the expected value from the alternative group. Dependence inequality impacts negotiations negatively because inequalities of power raise issues of fairness and legitimacy that are unlikely to arise under dependence equality (Lawler \& Yoon, 1993, 1996). The theory posits an interaction effect, predicting that the combination of high total and equal dependence on the group should produce an extra structural push toward repetitive exchange and the resulting group formation (that is, commitment) process. This structural cohesion effect is similar to Kollock's (1993) notion of running a 'loose accounting system’ 
where partners do not keep exact tabs on each party's contributions and allow each other to remain unbalanced for long periods; a higher total dependence allows partners to reach agreement at a wider range of prices at an earlier stage and equal dependence allows them to rectify imbalances in pay-offs later, given repeated transactions.

The theory posits an indirect sequence by which structural power- dependence conditions promote group formation (see Figure 8.1). This sequence starts with the exchange frequencies produced by the structure of dependence. One endogenous path operates through the uncertainty reduction effects of exchange frequency, and the second endogenous path operates through emotional-affective effects. Uncertainty reduction is a 'boundary-defining' process in which actors come to see the group to which they belong as setting them off from other relations or groups, that is, as having distinctiveness in social identity terms (Brewer, 1993). The emotional effects of exchange are described in terms of a 'social bonding' process through which the group becomes an object of intrinsic or expressive value (Lawler \& Yoon, 1996). Although the two endogenous processes are analytically and empirically independent, they converge in that each enhances perceptions that the group is a unifying or cohesive unit (see also Bollen \& Hoyle, 1990). This occurs because actors seek to interpret the source of positive emotions and the emerging group boundary prompts them to attribute the positive emotions to the group; the attribution, emotional buzz and salient boundary together induce actors to perceive their relationships to the group as having relational value. 
RCT predicts that perceived relational cohesion among actors is the proximal cause of various forms of commitment behavior. RCT has tested this prediction by treating stay behavior, token gifts and contribution to a joint venture as forms of commitment behavior. Stay behavior is a standard indicator of commitment in the literature and measures the degree to which actors remain in the focal relation in face of better or at least equal alternatives (Lawler \& Yoon, 1993, 1998). Token gifts are defined as the giving of resources to others in a unilateral way with no strings attached. Defined in this way, token gifts lack instrumental value and are symbolic of a shared group affiliation (Lawler et al., 1995). The theory treats the new joint venture as an Nperson social dilemma where not contributing is the dominant strategy and the well-known disparity between individual and collective rationality is present (Axelrod, 1984; Platt, 1973). Among the three, stay behavior in the face of better alternatives can be construed as more instrumental than the others, gift-giving as more expressive, and contribution behavior as more normative. The conditions and the processes in RCT have been tested by setting up a series of experiments in which these commitment behaviors are observed after actors have had the opportunity to establish a sense of relational cohesion through frequent or repetitive exchange (See Lawler \& Yoon, 1993, 1996, 1998; Lawler et al., 1995; Lawler et al., 2000).

Extrapolating Figure 8.1, RCT suggests further that given a group of multiple actors engaging in productive exchange ${ }^{2}$ members' greater total dependence or equality of dependence on the group promote member-to-group commitments, indirectly through the following steps: (1) High total dependence and equal dependencies generate more frequent, successful exchange among members. (2) More frequent exchange among these members increases (a) positive emotions or feelings and (b) the perceived predictability of the other members (uncertainty reduction). (3) Positive emotions and perceptions of predictability each make the relation more 
salient as a unifying, cohesive object in the situation. (4) Greater perceived cohesion produces a stronger commitment to a group, as reflected in stay behavior, gift-giving among members, and inclinations to undertake investments under risk or with the potential for malfeasance (Lawler \& Yoon, 1996; Lawler et al., 2000).

\section{The relational cohesion model of organizational commitment}

The relational cohesion model of organizational commitment is a direct application of RCT to organizational contexts. Organizational commitment is defined as individual employees' attachments to their membership organization. Following Parsons's (1951) and Kanter's (1968) distinctions, the model stipulates that an individual attachment can be instrumental (utilitarian), affective (emotional) or normative (moral). Instrumental commitment (IC) is based on the perceived benefits of remaining with an organization, whereas affective commitment (AC) is based on an emotional or cathectic attachment to the organization. Normative commitment (NC) is the attachment to the moral values and norms of an organization (Kanter, 1968).

Meyer et al. (1990) explicate the three dimensions with reference to the motivation underlying stay behavior. In an employment relationship, employees with instrumental commitment stay with an organization 'because they need to'; those with affective commitment stay 'because they want to'; and those with normative commitment stay 'because they feel they ought to' (Meyer et al., 1990: 710). O’Reilly and Chatman (1986) also propose a similar typology of psychological attachment (that is, compliance, identification and internalization), equivalent, respectively, to instrumental, affective and normative commitment. Most scholars employing multiple dimensions of organizational commitment agree that high organizational 
performance can be attained through an organization's capacity to mobilize more than instrumental commitment from its members (O'Reilly \& Chatman, 1986; Meyer et al., 1990; Mathieu \& Zajac, 1990).

Studies of organizational commitment have tended to investigate these three dimensions of commitment synchronically (Mathieu, 1991; Williams \& Hazer, 1986), focusing on differential causes of the three dimensions of commitment and differential consequences for organizations. In our model, we draw attention instead to the developmental aspect, that is, to how each dimension of commitment develops diachronically. Our model assumes that employees enter their membership organizations with instrumental motivations: there is an exchange with an organization, within which individual members invest their human resources in the organization in anticipation of salary, fringe benefits, social networks and reputation. Treating the instrumental motivation as one of the initial conditions however, our model pushes it further to understand how affective and normative commitments emerge from this instrumental base.

In the next sections, we elaborate the model. First, we review various forms of organizational capital that members depend on in exchange with organizations and the initial effects of these on instrumental commitment. Second, the two endogenous processes posited by RCT will be adapted to understand the development of affective commitment from an instrumental base. Third, the model will be expanded to explain how affective commitment generates normative commitment based on special forms of cultural capital in an organization. 


\section{Organizational capital, dependence, and instrumental commitment}

The first part of the model (see Figure 8.2) indicates that instrumentally motivated members experience varying degrees of dependence, reflected in the benefits they enjoy from different forms of organizational capital (for example cultural capital, social capital and human capital). The different forms of capital are, in part, grounded in and fostered by the organizational membership. Human capital is defined as a combination of an individual employee's sets of knowledge, skills, expertise, experiences and abilities (Becker, 1964); human capital is applied to their jobs and projects to generate value for the membership organization. Social capital is the network of relations employees rely on to secure some other benefits (Portes, 1998). Employees use social capital for instrumental purposes, perhaps to do their jobs more effectively by acquiring information or skills from other experts in the network. Cultural capital is the system of cultural resources that help members derive shared understandings, justifications and interpretations of organizational events and routines (Bourdieu, 1984; Lamont \& Lareau, 1988; Rentsch, 1990; Schein, 1985). Distinct from cultural forms such as rites and ceremonials, cultural capital consists of core assumptions, ideologies, missions, norms and values. Cultural capital works as a mental map, guiding appropriate ways of being and doing in organizational contexts (Argyris, 1993; Argyris \& Schon, 1974, 1978; James \& James, 1989; Schneider, 1975; Senge, 1990; Swidler, 1986). Cultural capital also encompasses an organization's reputation and its status in a given industry. As shown in Figure 8.2, the first prediction in our model is that as members perceive greater dependence on an organization for development and sustaining of human, social and cultural capital, they are likely to show greater instrumental commitment (IC) to that organization. 
Our model assumes that employees use their human capital in the organization for instrumental purposes, that is, to achieve their personal and professional goals. Among the most prominent goals of individuals is to increase the value or marketability of their human capital in internal and external labor markets. Employees also expect their membership organizations to be instrumental in making their career paths resistant to threats posed by unstable economic conditions (Rousseau, 1995; Rousseau \& Schalk, 2000). The acquisition and development of excellent human capital serves an instrumental purpose for the organizations as well. Organizations increasingly view and use human capital as a central strategic factor in gaining competitive advantage (Delery \& Doty, 1996; Huselid, 1995; Wright \& Snell, 1998; Lepak \& Snell, 1999; Pfeifer, 1994). An investment in human capital via education and training can generate a positive return on their investment (Becker, 1964).

Insert Figure 2 Here

Becker (1964) distinguishes between specific and general human capital investments. The former produces more dependence on the organization than the latter. Specific human capital investment refers to skills or knowledge that is useful only to one or a few employers, whereas general human capital investment is useful to virtually any employer. Organizations and their employees share the goal of increasing the return on such investments in human capital. On the other hand, employees want to increase the market value of their own human capital by investing more in general human capital, because such an investment reduces dependence on current employers; in contrast, employers want to invest in company-specific human capital, because such investment protects its return and makes employees dependent. ${ }^{3}$ All in all, to the 
extent that employees perceive their current employer as adding more to their human capital potential than alternative employers, they will experience greater dependence on the employing organization.

Portes describes social capital as 'the ability of actors to secure benefits by virtue of membership in social networks or relationships in social structures' (Portes, 1998:6). Social capital is not an individual actor's property; its value resides in the relational tie, which makes it more like a public good, especially when it is deployed within a collective boundary or a closed network (Coleman, 1988). Social capital requires a minimum level of mutual effort for the maintenance of commitment, trust, support and cooperation. Members' social capital can be based on either internal or external ties (Adler \& Kwon, 2002). Social capital in the form of external ties functions as a bridge that brings resources into an organization from other groups or networks outside the organization (Burt, 1992; Granovetter, 1973), whereas social capital in the form of internal ties functions as a communal bonding or sharing mechanism over individual resources within the boundary of a collectivity (Putnam, 2000; Coleman, 1988).

Despite this significant role, the dependence of individual members on this form of capital is largely implicit. Employees might not perceive its explicit value until they decide to leave an organization and search for a new organization. There is no common metric available to measure social relations as there is in the case of economic capital. Nevertheless when a member who has long benefited from a strong relationship with internal members seeks to move elsewhere, his or her dependence on social capital can emerge as an important factor. Similarly, when a member as a representative of an organization has also benefited from social networks with representatives of other organizations, such dependence also might come to the foreground. 
As with specific human capital, as the organization produces more non-transferable social capital, an employee becomes more dependent on the organization.

The model in Figure 8.2 also theorizes that employees' dependence on the organization is shaped by the degree that the organization produces access to cultural capital. We define cultural capital as a system of cultural resources (for example ideologies, missions, norms and values) which help members derive shared understanding, justifications and interpretations of organizational events and routines (Bourdieu, 1984; Lamont \& Lareau, 1988; Rentsch, 1990; Schein, 1985). Much research indicates how cultural capital in the forms of ideologies, missions and values affects various organizational activities and behavior, such as organization-person fit (O’Reilly \& Caldwell, 1981; O’Reilly \& Chatman, 1986; Chatman, 1989), organizational learning (Senge, 1990; Nadkarni, 2003) and organizational transformation (Collins \& Porras, 1996). However these forms of cultural capital do not foster members' instrumental dependence, because they mainly subsume members' normative orientations.

Instrumental dependence on cultural capital produced by organizations emerges instead from a special form of cultural capital: the status of an organization in its industry is an example of this. An organization's industry status is one of its cultural assets or resources, because organizational status is activated by cultural beliefs shared among organizations in a field of industry. Especially when evaluators in the labor market have no information on a given individual, they infer the status value and performance expectation of that individual from his or her membership organization's status and performance expectation. Organizational status is carried over in determining members' status in the market. Higher organizational status also becomes a source of pride for members that differs from the respect that results from an individual's status within an organization (Hogg, 1992; Hogg \& Turner, 1985; Tyler, 2001). This 
organizational status argument predicts that, other things being equal, the higher the status and performance expectation of an organization within an industry, the greater is its members' dependence on this aspect of cultural capital. Most job candidates also have this status information in mind when they search prospective workplaces.

In brief, the first part of our model (see Figure 8.2) predicts that employees develop instrumental commitment (IC) due to the degree that organizations enhance their human capital (for example training and education), social capital (for example social support and relationships) and cultural capital (for example organizational reputation). The instrumental commitment in turn induces employees to stay with that organization. Stay behavior is a key behavioral indicator of instrumental commitment (O’Reilly \& Chatman, 1986).

\section{Endogenous processes and affective commitment}

The relational cohesion model of organizational commitment extrapolates its key theoretical constructs from those in Relational Cohesion Theory (see Figure 8.2). Experiences of empowerment are, in RCT, equivalent to the accomplishment of repetitive exchange; organizational membership support is equivalent to predictability or reduced uncertainty; and positive work emotions are equivalent to positive emotions from exchange in RCT. As a part of these two endogenous processes, the relational cohesion model of organizational commitment proposes that a member's experience of empowerment triggers two pathways (emotional bonding and boundary defining) that lead to a sense of unity and affective commitment (AC).

Our model treats an organization's dependence on its member as a moderating factor for the impact of the member's perception of dependence on the experience of empowerment. 
Empowerment in our model refers to a state in which employees experience enhanced efficacy or sense of control in achieving personal and professional goals through their organization (Yoon, 2001; Bandura, 1982; Conger \& Kanungo, 1988; Kanungo, 1979; Thomas \& Velthouse, 1990). The organization's dependence, by offsetting the employee's own dependence, provides the employee with empowerment opportunities and experience. The more mutual the dependence, the more likely are employees to adjust their goals to achieve joint tasks and goals. Tsui and her associates (Tsui et al., 1997) confirm that mutual dependence (or investment) in the employment relationship enhances employees' commitments and organizational citizenship behavior as well as performance (see also Lawler, 1986).

In Figure 8.2, organizational membership support refers to individual members' beliefs that their organization will treat them as deserving members when the organization is under uncertainty, risk or financial difficulties. As employees perceive greater membership support in such situations, they are likely to experience greater certainty or predictability in the future of the relationship. Organizational membership support is adapted from Eisenberger and others' (Eisenberger et al., 1986; Rhoades \& Eisenberger, 2002; Tyler, 2001) perceived organizational support (POS) by highlighting the aspect of membership in exchange for support (for example even if my organization found a person who could do my job better, they would not replace me; when my job is eliminated, my organization will transfer me to a new job rather than lay me off). We predict that empowered employees are likely to perform better and, given these contributions, be accepted as more deserving members by an organization. In a similar context, Hollander (1958) also indicates that members' repeated contributions can serve as credits that can be used to draw membership support from the organization, especially when they make unexpected mistakes, perform poorly, or fail at specific tasks. 
Relational Cohesion Theory considers two facets of positive emotions: pleasure/satisfaction and interest/excitement (Izard, 1991; Watson \& Tellegen, 1985; Larsen \& Diener, 1992). Pleasure/satisfaction is 'feeling gratified', and interest/excitement is 'feeling energized'. Lawler and Yoon $(1993,1996)$ describe interest/excitement as a forward-looking emotion, one based on an awareness of potential satisfaction in anticipation of possible gains, and pleasure/satisfaction as a backward-looking emotion, which occurs after something has been gained. Assuming partners in an exchange relation simultaneously look forward and backward, RCT explores whether the corresponding emotions mediate commitment behavior. Following this lead, we construe positive work emotion as a positively gratified or energized state resulting from the appraisal of one's work experiences. Our model adopts both facets of positive emotions from RCT: pleasure/satisfaction and interest/excitement.

Rediscovering different types of affect in the workplace in the mid-1980s and 1990s, organizational researchers have argued that job satisfaction is limited in understanding various affective work experiences because its measurement captures mainly evaluative and cognitive states (Brief \& Weiss, 2002). Our current conceptualization addresses this problem by incorporating interest/excitement as another key affective state and by treating pleasure/satisfaction as a global emotion beyond specific job evaluation. As a motivating state of curiosity and fascination (Izard, 1991), interest/excitement captures more active aspects of affective experiences and accounts for high levels of enthusiasm.

We argue that when employees experience more empowerment, they tend to be emotionally energized and gratified, and they attribute these feelings to the organization (Lawler, 1992a). RCT theory does not explain or theorize the conditions under which the emotions are attributed to the social unit. However the Affect Theory of Social Exchange (Lawler, 2001, 
2002) takes up this issue. According to that theory, this attribution of feelings to the social unit occurs when the task engaged in by actors is high in jointness, and when it is likely to generate a sense of shared responsibility for results produced. Applied to our organizational commitment model, the greater the mutual dependence in the individual-organization relationship, the greater the degree that individuals will see their own individual efficacy as intertwined with the efficacy of the organization; in this sense, the individual experience of empowerment involves a sense of jointly accomplishing important tasks with the organization as such; this jointness and shared responsibility of empowerment make employees attribute their emotions in part to the relationship with the organization (Lawler, 2002). The emerging membership boundary along with organizational membership support also prompts members to interpret the sources of their positive emotions and attribute them to the member-organization relationship. As members begin to perceive such a relationship as an emotionally and cognitively binding force, the relationship becomes objectified as a valuable third force unifying them with the organization. The current model predicts that this sense of unity is the proximal cause of affective commitment (see Figure 8.2). That is, the model predicts that instrumental commitment (IC) develops into affective commitment (AC) when employees perceive a sense of unity with their membership organization.

\section{Moral value and normative commitment}

We conceptualized instrumental commitment as an attachment to the utilitarian value of an organization and affective commitment as an attachment to the relation with an organization. Similarly, we define normative commitment as an attachment to the moral-normative aspects of 
an organization. This definition of normative commitment is similar to Buchanan's (1974) definition. Buchanan construes commitment in terms of an attachment to the long-term goals (or visions) and values of an organization. Our definition is also suggested by Wiener's (1982) notion of normative commitment as personal convictions in support of the value system (for example missions and goals) of an organization. Weiner differentiates this form of normative commitment from the conventional normative commitment built upon generalized loyalty and duty. The standard definition of normative commitment emphasizes the loyalty or obedience of members, whereas Weiner's defines normative commitment as a reflection of personal conviction; the latter approach assumes individual choices among distinctive value systems and individual initiatives to realize the chosen one (Wiener, 1982).

The moral value of an organization is determined primarily by the cultural capital the organization holds. To elaborate the role of cultural capital in normative commitment, we use the concepts of organizational mental model and organizational culture, as characterizations of 'espoused theory', based on Senge (1990) and Argyris and Schon (1974, 1978). Argyris and Schon's organizational theory differentiates theory in use from espoused theory. They slate*. 'When someone Is ashed how he would behave under certain circumstances, the answer he usually gives is his "espoused theory of action" for that situation. This is the theory of action to which he gives allegiance, and which, upon request, he communicates to others. However, the theory that actually governs his actions is this theory in use' (Argyris \& Schon, 1974: 6-7).

Certain components of cultural capital act as either theory in use or espoused theory in an organization. Culure as theory in use is embedded in the cultural capital component as a tool kit or as a set of habitualized routines (Swidler, 1986). Without questionning its validity, members use it as a heuristic device to make sense of their environments (Argyris, 1993). In constrast, the 
culture as an espoused theory is the set of ideologies, values and purposes that constitutes the 'core mental model' of an organization (Argyris, 1993; Collins \& Porras, 1996; Gentner \& Stevens, 1983; Kieras \& Bovair, 1984; Nadkami, 2003). A mental model works as a cognitive filter or map through which people consciously make sense of significant problems; people utilize it explicitly when they need to justify the hows and whys of important issues in a problem situation (Senge, 1990; Nadkarni, 2003). Similarly, the 'organizational mental model' can be construed as a system of visions, values and purposes that provides moral justification or legitimacy for an organization. This notion of organizational mental model is also reflected in Argyris's (1993) Model II, Collins and Porras's (1996) corporate ideology, Swidler's (1986) cultural ideology and Weber's (1946) metaphor of switchmen. As implied by the nature of values, visions and purposes, mental models become the foundation of an organization's moral value.

Building upon these conceptualizations, we now define normative commitment formally as members' attachments to the moral values of their membership organization's mental model. With this definition in mind, our model proposes a mechanism through which affective attachment generates normative attachment. This mechanism requires a series of cognitive and evaluative steps (Fishbein \& Ajzen, 1975; Wiener, 1988): First, members attempt to make broad sense of their affective attachment, that is, from the perspective of their organization's mental model (visions, purposes and values). Second, once the moral meaning of their relationship to an organization is primed by the organizational mental model, then members begin to perceive incipient moral values of the organizational mental model. Finally, members develop normative attachment to the organization, when they realize that the organizational mental model is also congruent with their personal values. 
Once members develop normative commitment to their organization, they use the set of organizational mental models (that is, visions, purposes and values) more deliberatively in justifying and legitimating critical events in their organization. That is, they use the mental model purposively in explaining the hows and whys of significant issues in a problem situation (Nadkarni, 2003). In particular, decisions that members reach are justified or legitimized more explicitly by the core values an organization holds (Barrett, 2003). Members incorporate corporate visions, values and missions in articulating their own personal mental models (Levin, 2000). This infusion of a corporate mental model into members' moral orientations in turn drives members' greater engagement in realizing it by putting substantial effort and sacrifice into their action.

Despite such powerful explanatory potential, normative commitment has not drawn much research attention to date (see Wiener, 1982, 1988 for an exception). One reason is that normative commitment is conceptualized in terms of moral judgement and attitudes, making its scientific scrutiny difficult. Our model addresses this problem by defining normative commitment as an attachment to the organizational mental model that lays a moral legitimacy for the organization. Another reason is that some organizations may not yet have established their salient mental models as a foundation for normative commitment. Nonetheless scholars have begun to recognize the importance of normative commitment in understanding more dynamic aspects of organizational activities beyond performance and order (Collins \& Porras, 1996; Kirkpatrick et al., 2002; Kotter, 1996; Larwood et al., 1995; Wiener, 1982; Lau \& Woodman, 1995; Herscovitch \& Meyer, 2002). ${ }^{4}$ Our model opens an avenue for such research.

Along with this developmental focus, our model identifies various behaviors as reflections of these underlying dimensions of attachment. For example turnover and intention to 
stay are among the main behavioral indicators of instrumental commitment (Mathieu, 1991; Mathieu \& Zajac, 1990; Williams \& Hazer, 1986); as in gift-giving in RCT, organizational citizenship behavior can be construed as a behavioral indication of affective attachment (Organ, 1997; Podsakoff \& MacKenzie, 1997; Podsakoff et al., 2000); extraordinary contributions and individual sacrifice are behavioral expressions of normative commitment (Wiener, 1982).

The reciprocal paths in Figure 8.2 suggest that if such affective and normative commitment behaviors are collectively expressed among members, these lay the foundation for ritualization of processes within an organization and legitimation for an organization as such. Specifically, the collective behavioral expression of affective commitment through extra role behavior or organizational citizenship behavior constitutes organizational rituals invoking a shared membership identity and its affective value for all members (Durkheim, 1915). Similarly, the collective behavioral expression of sacrifices and significant contributions among members becomes a strong source of validation for those members who seek affirmation of their personal beliefs about the value of the organizational membership (Fishbein \& Ajzen, 1975; Scott, 1987; Walker et al., 1986). Furthermore the collectively validated organizational mental model works as a guiding framework legitimizing the current organizational structure and processes. Ritualization and legitimation offer ways of understanding why and how individual actions are organized and intertwined at the collective level. 


\section{Conclusions}

This study applies Relational Cohesion Theory (Lawler \& Yoon, 1993, 1996, 1998; Lawler et al., 2000; Thye et al., 2002) to the important task of understanding how employees within organizations develop affective and normative commitments from purely instrumental commitments. Instrumental commitment is the degree to which dependence leads individual members to believe that they can fulfill their personal and professional goals by remaining in their current organizations as opposed to joining alternative organizations. Affective commitment is the degree to which members perceive the relationship to the organization to be a salient force having significant value in itself; normative commitment is the degree that members ascribe moral value to their organization's core cultural system as reflected in the organizational mental model. From a developmental process, affective commitment develops when instrumental commitment generates a sense of unity, through boundary defining and emotional bonding processes. Normative commitment emerges and builds in strength when affectively committed relations acquire a larger moral meaning, with reference to a corporate mental model, such that members believe in the moral value of the organization. It adds a dimension to social identification processes (Meyer et al., 1990; O’Reilly \& Chatman, 1986; Wiener, 1982). Instrumental commitment entails a utilitarian identification of an individual's goals with an organization's short-term operation and performance goals (Rusbult, 1980, 1983). Affective commitment entails an emotional bonding or identification of the self with the organizational identity (Porter et al., 1974; Meyer et al., 1990). Normative commitment involves a correspondence between an individual's value orientation with that of an organization, that is, a moral identification with the organization (Buchanan, 1974; Wiener, 1982, 1988). 
Parts of the relational cohesion model of organizational commitment have been tested in several field studies. Yoon and others (Yoon et al., 1994; Yoon \& Lim, 1999; Yoon \& Thye, 2000) have confirmed the role of social and human capital in promoting affective and instrumental commitment. Other studies (Yoon et al., 1996; Yoon, 2001) have investigated the path from social and human capital to experiences of empowerment, and demonstrated their significant roles for psychological empowerment. Yoon and Thye (2002) have documented the independent effects of the two endogenous processes (that is, boundary defining and emotional bonding) in organizational commitment. A comprehensive test of our model is a task for future research.

A key message of our model is the role of affective commitment in bridging instrumental and normative commitment. Affective attachment is important because it promotes sociability, that is, the capacity of an organization to facilitate workplaces in which open dialogue, voluntary cooperation and trustful interaction occur even among members who have not known each other (Onyx \& Bullen, 2000; Kreijns et al., 2002; Leana \& Van Buren, 1999). If individual members are committed affectively to an organization, this enhances the salience of organizational membership, thereby prompting members to initiate more interactions with fellow employees (see also Hogg, 1992; Tajfel \& Turner, 1986). Such a common social identity also helps an organization overcome structural cleavages within itself by strengthening the overarching organizational identity. Low sociability for example inhibits individually-oriented members from sharing information with other members who need it. Social capital cannot be created and replenished without the generation of spontaneous collaboration among network members, and low sociability reduces this. Among the three forms of organizational commitment, the affective form is the primary determinant of sociability. Overall, we suspect that without affective 
commitment, organizations with substantial human resources and cultural capital would perform less well, due to insufficient sociability.

The roles of instrumental, normative and affective commitment can be likened to the functional system of a motor vehicle: instrumental commitment provides the fuel energizing members by helping them fulfill their individual goals within an organization; affective commitment is an engine transforming the fuel into collective power or efficacy through a healthy and trustful community of interaction; and normative commitment is a steering wheel directing the collective efficacy or power to whatever destination the organization desires to reach. 


\section{Notes}

- This chapter was supported by the Korea Research Foundation (Grant \#: 2001-042- COO 135) awarded to the first author. The authors thank Shane Thye for constructive comments.

1. This part of the explanation is developed more explicitly by Lawler's affect theory of social exchange (Lawler, 2001, 2002). The theory indicates that different structural forms of exchange entail tasks with different degrees of jointness and shared responsibility. Shared responsibility and task jointness in turn lead actors to attribute distinct types of emotions to relevant social units as the context for actors' common focus and activity.

2. Lawler et al. (2000) conceptualize productive exchange in terms of the following properties: (1) productive exchange involves mutiple actors who combine resources to produce a joint outcome such as a paper authored by three actors or a department potluck dinner; (2) the joint production entails higher degrees of interdependence among members and considerable coordination problems; (3) unlike dyadic exchange in which inputs and benefits flow from person-to-person, inputs in a productive exchange flow from person- to-group and benefits flow from group-to-person.

3. Employees also make extra investments around their own human capital in a form known as side bets (Becker, 1964). These side bets also increase members' dependence on their membership organizations. For instance an employee might make a side bet in the form of buying a house near the company to save commuting hours or to transfer their kids into a particular school district. These side bets become sunk costs for members, in that their investment value is realized only insofar as they stay with a given organization. 
4. Collins and Porras (1996) demonstrate that world class companies with records of longterm excellence have the communality in virtue of which their employees - including CEOs - are all normatively committed to their mental models and, moreover, that they cultivate such environments explicitly; Kirkpatrick et al. (2002) and Kotter (1996) show how salient visions and purposes commit employees to their organization's transformation efforts to adapt to pressures of competition. In a nutshell, Wiener (1982) concludes that only normatively committed people respond seriously to an organization's requests for substantial investment, effort and sacrifice. 
Figure 1



Source: Adapted from Lawler et al. (2000).

Figure 8.1 Relational cohesion theory (RCT) 
Figure 2

Legitimation

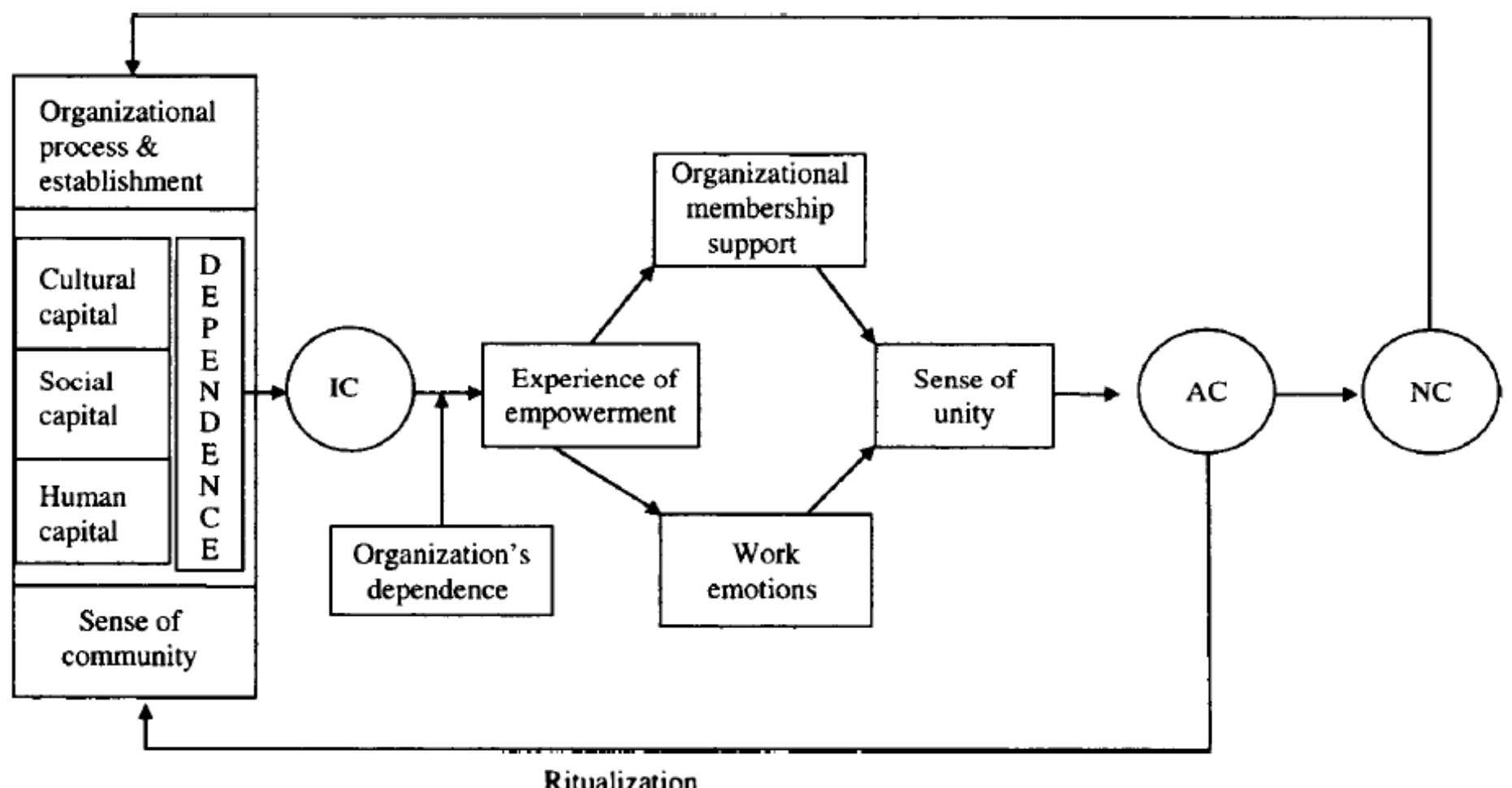

Ritualization

Figure 8.2 Relational cohesion model of organizational commitment 


\section{References}

Adler, P.S. \& Kwon, S. (2002), Social capital: prospects for a new concept, Academy of Management Review, 27, 17-40.

Argyris, C. (1993), On organizational learning, Cambridge, MA: Blackwell Publishers.

Argyris, C. \& Schon, D. (1974), Theory in Practice: Increasing Professional Effectiveness, San Francisco, CA: Jossey-Bass.

Argyris, C. \& Schon, D. (1978), Organizational Learning: A Theory of Action Perspective, Reading, MA: Addison Wesley.

Axelrod, R. (1984), The Evolution of Cooperation, New York: Basic Books.

Bacharach, S.B. \& Lawler, E.J. (1981), Bargaining: Power, Tactics, and Outcomes, San Francisco, CA: Jossey-Bass.

Bandura, A. (1982), Self-efficacy mechanism in human agency, American Psychologist, 37, 12247.

Barrett, R. (2003), Improving your cultural capital, Industrial Management, 45, 20-24.

Becker, G.S. (1964), Human Capital, New York: Columbia University Press.

Becker, H.S. (1960), Notes on the concept of commitment, American Journal of Sociology, 66, $32-40$.

Blau, P.M. (1964), Exchange and Power in Social Life, New York: Wiley.

Blau, P.M. (1977), A macrosociological theory of social structure, American Journal of Sociology, 83, 26-54.

Bollen, K.A. \& Hoyle, R.H. (1990), Perceived cohesion: a conceptual and empirical examination, Social Forces, 69, 479-504. 
Bourdieu, P. (1984), Distinction: A Social Critique of the Judgment of Taste, Cambridge, MA: Harvard University Press.

Brewer, M.B. (1993), Social identity, distinctiveness, and ingroup homogeneity, Social Cognition, 11, 150-64.

Brief, A.P. \& Weiss, H.M. (2002), Organizational behavior: affect in the work place, Annual Review of Psychology, 53, 279-307.

Buchanan, B. (1974), Building organizational commitment: the socialization of managers in work organizations, Administrative Science Quarterly, 19, 533-47.

Burt, R.S. (1992), Structural Holes: The Social Structure of Competition, Cambridge, MA: Harvard University Press.

Chatman, J.A. (1989), Improving interactional organizational research: a model of personorganization fit, Academy of Management Review, 14, 333-49.

Coleman, J.S. (1988), Social capital in the creation of human capital, American Journal of Sociology, 94, 95-120.

Coleman, J.S. (1990), Foundations of Social Theory, Cambridge, MA: Harvard University Press.

Collins, J. \& Porras, J.I. (1996), Building your company's vision, Harvard Business Review, 74, $65-77$.

Collins, R. (1981), On the microfoundations of macrosociology, American Journal of Sociology, $86,984-1014$

Conger, J.A. \& Kanungo, R.N. (1988), The empowerment process: integrating theory and practice, Academy of Management Review, 13, 471-82.

Cook, K.S. \& Emerson, R. (1978), Power, equity, and commitment in exchange networks, American Sociological Review, 27, 40-41. 
Delery, J.E. \& Doty, D.H. (1996), Modes of theorizing in strategic human resource management: tests of universalistic, contingency, and configurational performance prediction, Academy of Management Journal, 39, 802-35.

Durkheim, E. (1915), The Elementary Forms of Religious Life, New York: Free Press.

Eisenberger, R., Huntington, R., Hutchison, S. \& Sowa, D. (1986), Perceived organizational support, Journal of Applied Psychology, 71, 500-507.

Emerson, R.M. (1972), Exchange theory Part I: A psychological basis for social exchange, in Berger, J., Zelditch, M., Jr. \& Anderson, B. (eds), Sociological Theories in Progress, vol. 2, Boston, MA: Houghton-Mifflin, pp. 38-57.

Emerson, R.M. (1981), Social exchange theory, in Rosenberg, M. and Turner, R.H. (eds), Social Psychology: Sociological Perspectives, New York: Basic Books, pp. 30-65.

Fishbein, M. \& Ajzen, I. (1975), Belief Attitude, Intention, and Behavior. Reading, MA: Addison-Wesley.

Frank, R.H. (1988), Passions within Reasons: The Strategic Role of Emotions, New York: W.W. Norton.

Frank, R.H. (1993), The strategic role of emotions: reconciling over and undersocialized accounts of behavior, Rationality and Society, 5,160-84.

Gentner, D. \& Stevens, A. (1983), Mental Models, Hillsdale, NJ: Erlbaum.

Giddens, A. (1984), The Constitution of Society, Berkeley, CA: University of California Press.

Gouldner, A.W. (1960), The norm of reciprocity: a preliminary statement, American Sociological Review, 25, 161-78.

Granovetter, M.S. (1973), The strength of weak ties, American Journal of Sociology, 78, 136080. 
Granovetter, M.S. (1985), Economic action and social structure: the problem of embeddedness, American Journal of Sociology, 91, 481-510.

Hardin, G. (1968), Tragedy of the commons, Science, 162, 1243-8.

Hechter, M. (1987), Principles of Group Solidarity. Berkeley, CA: University of California Press.

Herscovitch, L. \& Meyer, J.P (2002), Commitment to organizational change: extension of a three-component model, Journal of Applied Psychology, 87, 474-87.

Hochschild, A.R. (1983), The Managed Heart: Commercialization of Human Feeling, Berkeley, CA: University of California Press.

Hogg, M.A. (1992), The Social Psychology of Group Cohesiveness: From Attraction to Social Identity, New York: New York University Press.

Hogg, M.A. \& Turner, J.C. (1985), Interpersonal attraction, social identity, and psychological group formation, European Journal of Social Psychology, 15, 51-66.

Hollander, E.P. (1958), Conformity, status, and idiosyncracy credit, Psychological Review, 65, $117-27$.

Homans, G.C. (1961), Social Behavior, New York: Harcourt, Brace \& World.

Huselid, M.A. (1995), The impact of human resource management practices on turnover, productivity, and corporate financial performance. Academy of Management Journal, 38, 635-72.

Izard, Carroll E. (1991), The Psychology of Emotion, New York: Plenum Press.

James, L.A. \& James, L.R. (1989), Integrating work environment perceptions: explorations in the measurement of meaning, Journal of Applied Psychology, 74, 739-51. 
Kanter, R.M. (1968), Commitment and social organization: a study of commitment mechanisms in utopian communities, American Sociological Review, 33, 499-517.

Kanungo, R. (1979), The concepts of alienation and involvement revisited, Psychological Bulletin, 86, 119-38.

Kieras, D. \& Bovair, S. (1984), The role of mental models in learning to operate a device. Cognitive Science, 8, 255-73.

Kirkpatrick, S.A., Wofford, J.C. \& Baum, J.R. (2002), Measuring motive imagery contained in the vision statement. Leadership Quarterly, 13, 139-50.

Kollock, P. (1993), An eye for an eye leaves everyone blind: cooperation and accounting systems, American Sociological Review, 58, 768-85.

Kollock, P. (1994), The emergence of exchange structures: an experimental study of uncertainty, commitment, and trust, American Journal of Sociology, 100, 315-45.

Kotter, J.P. (1996), Leading Change, Boston, MA: Harvard Business Press.

Kreijns, K., Kirschner, P.A. \& Jochems, W. (2002), The sociability of computer-supported collaborative learning environments, Journal of Education Technology and Society, 5, 822.

Lamont, M. \& Lareau, A. (1988), Cultural capital: allusions, gaps, and glissandos in recent theoretical developments, Sociological Theory, 6, 153-68.

Larsen, R.J. \& Diener, E. (1992), Promises and problems with the circumplex model of emotion, in Clark, M.S. (ed.), Emotion, Newbury Park, CA: Sage Publications, pp. 25-9.

Larwood, E.J., Fable, C.M., Kriger, M.P. \& Miesing, P. (1995), Structure and meaning of organizational vision, Academy of Management Journal, 38, 740-70. 
Lau, C. \& Woodman, R.W. (1995), Understanding organizational change: a schematic perspective, Academy of Management Journal, 38, 537-54.

Lawler, E.E., III. (1986), High-involvement Management, San Francisco, CA: Jossey-Bass.

Lawler, E.J. (1992a), Choice processes and affective attachments to nested groups: a theoretical analysis, American Sociological Review, 57, 327-39.

Lawler, E.J. (1992b), Power processes in bargaining, Sociological Quarterly, 33, 17-34.

Lawler, E.J. (2001), An affect theory of social exchange, American Journal of Sociology, 107, $321-52$.

Lawler, E.J. (2002), Micro social orders, Social Psychology Quarterly, 65, 4-17.

Lawler, E.J. \& Ford, R. (1993), Metatheory and friendly competition in theory growth: the case of power processes in bargaining, in Berger, J. \& Zelditch, M., Jr. (eds), Theoretical Research Programs: Studies in Theory Growth, Stanford, CA: Stanford University Press, pp. 172-210.

Lawler, E.J., Thye, S. \& Yoon, J. (2000), Emotion and group cohesion in productive exchange, American Journal of Sociology, 106, 616-57.

Lawler, E.J. \& Yoon, J. (1993), Power and the emergence of commitment behavior in negotiated exchange, American Sociological Review, 58, 465-81.

Lawler, E.J. \& Yoon, J. (1996), Commitment in exchange relations: test of a theory of relational cohesion, American Sociological Review, 61, 89-108.

Lawler, E.J. \& Yoon, J. (1998), Network structure and emotion in exchange relations, American Sociological Review, 63, 871-94.

Lawler, E.J., Yoon, J., Baker, M. \& Large, M.D. (1995), Mutual dependence and gift giving in exchange relations, Advances in Group Processes, 12, 271-98. 
Leana, C.R. \& Van Buren, H.J. (1999), Organizational social capital and employment practices, Academy of Management Review, 24, 538-55.

Lepak, D.P. \& Snell, S.A. (1999), The human resource architecture: toward a theory of human capital allocation and development, Academy of Management Review, 24, 31—48.

Levin, I.M. (2000), Vision revisited: telling the story of the future, Journal of Applied and Behavioral Science, 36, 91-107.

Macy, M.W. (1993), Backward looking social control, American Sociological Review, 58, 81936.

Mathieu, J.E. (1991), A cross-level nonrecursive model of the antecedents of organizational commitment and satisfaction, Journal of Applied Psychology, 76, 607-18.

Mathieu, J.E. \& Zajac, D. (1990), A review and meta-analysis of the antecedents, correlates, and consequences of organizational commitment, Psychological Bulletin, 108, 171-94.

Meyer, J.P., Allen, N.J. \& Gellatly, I.R. (1990), Affective and continuance commitment to the organization: Evaluation of measures and analysis of concurrent and time-lagged relations, Journal of Applied Psychology, 75, 710-20.

Molm, L. (1990), Structure, action, and outcomes: the dynamics of power in social exchange, American Sociological Review, 55, 427-47.

Molm, L. (1994), Dependence and risk: transforming the structure of social exchange. Social Psychology Quarterly, 57, 163-89.

Molm, L. \& Cook, K. (1995), Social exchange and exchange networks, in Cook, K.S., Fine, G.A. \& House, J.S. (eds), Sociological Perspectives on Social Psychology, Boston, MA: Allyn and Bacon, pp. 209-35. 
Nadkami, S. (2003), Instructional methods and mental models of students: an empirical investigation, Academy of Management Learning and Education, 2, 335-51.

Onyx, J. \& Bullen, P. (2000), Measuring social capital in five communities, Journal of Applied Behavioral Science, 36, 23-42.

O’Reilly, C.A. \& Chatman, J. (1986), Organizational commitment and psychological attachment: the effects of compliance, identification, and internalization on prosocial behavior, Journal of Applied Psychology, 71,492-9.

O’Reilly, C.A. \& Cadwell, D.F. (1981), The commitment and job tenure of new employees: some evidence of post-decisional justification, Administrative Science Quarterly, 26, 597-616.

Organ, D.W. (1997), Organizational citizenship behavior: it's construct clean-up time, Human Performance, 10, 85-97.

Parsons, T. (1951), The Social System, New York: Free Press.

Pfeffer, J. (1994), Competitive Advantage through People: Unleashing the Power of the Work Force, Boston, MA: Harvard Business School Press.

Platt, I. (1973), Social traps, American Psychologist, 28,641-51.

Podsakoff, P.M. \& MacKenzie, S.B. (1997), The impact of organizational citizenship behavior on organizational performance: a review and suggestions for future research, Human Performance, 10, 133-51.

Podsakoff, P.M., MacKenzie, S.B., Paine, J.B. \& Bachrach, D.G. (2000), Organizational citizenship behaviors: a critical review of the theoretical and empirical literature and suggestions for future research, Journal of Management, 26, 513-63. 
Porter, K., Steers, R., Mowday, R. \& Boulian, P. (1974), Organizational commitment, job satisfaction, and turnover among psychiatric technicians, Journal of Applied Psychology, $59,603-9$.

Portes, A. (1998), Social capital: its origins and applications in modern sociology, Annual Review of Sociology, 24, 1-24.

Pruitt, D. \& Kimmel, M.J. (1977), Twenty years of experimental gaming: critique, synthesis, and suggestions for the future, Annual Review of Psychology, 28, 363-92.

Putnam, R.D. (2000), Bowling Alone: The Collapse and Revival of American Community, New York: Simon \& Schuster.

Rentsch, J.R. (1990), Climate and culture: interaction and qualitative differences in organizational meanings, Journal of Applied Psychology, 75, 668-81.

Rhoades, L. \& Eisenberger, R. (2002), Perceived organizational support: a review of the literature, Journal of Applied Psychology, 87, 698-714.

Rousseau, D.M. (1995), Psychological Contract in Organizations, Thousand Oaks, CA: Sage Publications.

Rousseau, D.M. \& Schalk, R. (2000), Psychological Contracts in Employment: Cross-national Perspectives, Thousand Oaks, CA: Sage Publications.

Rusbult, C.E. (1980), Commitment and satisfaction in romantic associations: a test of the investment model, Journal of Experimental Social Psychology, 16, 172-86.

Rusbult, C.E. (1983), A longitudinal test of the investment model: the development (and deterioration) of satisfaction and commitment in heterosexual involvement, Journal of Personality and Social Psychology, 60, 53-78. 
Rusbult, C.E. \& Buunk, B.P. (1993), Commitment processes in close relationships: an interdependence analysis, Journal of Social and Personal Relationships, 10, 175-204.

Rusbult, C.E., Martz, J.M. \& Agnew, C.R. (1998), The investment model scale: Measuring commitment level, satisfaction level, quality of alternatives, and investment size, Personal Relationships, 5, 357-91.

Schein, E.H. (1985), Organizational Culture and Leadership: A Dynamic View, San Francisco, CA: Jossey-Bass.

Schneider, B. (1975), Organizational climates: an essay, Personnel Psychology, 28, 447-79.

Scott, R.W. (1987), Organizations: Rational, Natural, and Open Systems, Englewood Cliffs, NJ: Prentice-Hall.

Senge, P. (1990), The Fifth Discipline: The Art and Practice of the Learning, New York: Doubleday.

Skvoretz, J. \& Lovaglia, M.J. (1995), Who exchanges with whom: structural determinants of exchange frequency in negotiated exchange networks, Social Psychology Quarterly, 58, 163-77.

Swidler, A. (1986), Culture in action: symbols and strategies, American Sociological Review, 51, 273-86.

Tajfel, H. \& Turner, J.C. (1986), The social identity theory of intergroup behavior, in Worchel, S. \& Austin, W.G. (eds), Psychology of Intergroup Relations, Chicago, IL: Nelson-Hall, pp. 7-24.

Thibaut, J.W. \& Kelley, H.H. (1959), The Social Psychology of Groups, New York: Wiley. Thomas, K.W. \& Velthouse, B.A. (1990), Cognitive elements of empowerment: an interpretive model of intrinsic task motivation, Academy of Management Review, 15, 666-81. 
Thye, S., Yoon, J. \& Lawler, E.J. (2002), Relational cohesion theory: review of a research program, Advances in Group Processes, 19, 89-102.

Tsui, A., Pearce, J.L., Porter L.W. \& Tripoli, A.M. (1997), An alternative approaches to the employee-organization relationship: does investment in the employees pay off? Academy of Management Journal, 40, 1089-121.

Tversky, A. \& Kahneman, D. (1974), Prospect theory: an analysis of decision under risk, Science, 185, 1124-31.

Tyler, T.R. (2001), Cooperative in organizations: a social identity perspective, in Hogg, M.A. \& Terry, D.J. (eds), Social Identity Processes in Organizational Contexts, Philadelphia: Psychology Press, pp. 149-79.

Walker, H., Thomas, G.M. \& Zelditch, M. (1986), Legitimation, endorsement, and stability, Social Forces, 64, 620-43.

Watson, D. \& Tellegen, A. (1985), Toward a consensual structure of mood, Psychological Bulletin, 98, 219-35.

Weber, M. (1946), The social psychology of the world religion, in Gerth, H.H. \& Mills, C.W. (eds), From Max Weber, New York: Oxford University Press, pp. 267-301.

Wiener, Y. (1982), Commitment in organizations: a normative view, Academy of Management Review, 7,418-28.

Wiener, Y. (1988), Forms of value systems: a focus on organizational effectiveness and cultural change maintenance, Academy of Management Review, 13, 534-45.

Williams, L.J. \& Hazer, J.T. (1986), Antecedents and consequences of satisfaction and commitment in turnover models: a reanalysis using latent variable structural equation models, Journal of Applied Psychology, 71, 219-31. 
Williamson, O.E. (1981), The economics of organization: the transaction cost approach, American Journal of Sociology, 87, 549-77.

Wright, P.M. \& Snell, S.A. (1988), Toward a unifying framework for exploring fit and flexibility in strategic human resource management, Academy of Management Review, 23, 756-72.

Yamagishi, T. (1995), Social dilemmas, in Cook, K. and Fine, G. \& House, J. (eds), Sociological Perspectives on Social Psychology, Boston, MA: Allyn \& Bacon, pp. 311-34.

Yoon, J. (2001), The role of structure and motivation for workplace empowerment, Social Psychology Quarterly, 64, 110-23.

Yoon, J., Baker, M. \& Ko, J. (1994), Effects of interpersonal attachment on organizational commitment: subgroup hypothesis revisited, Human Relations, 47, 329-51.

Yoon, J., Han, N. \& Seo, Y. (1996), Sense of control among hospital employees: tests of choice process, empowerment, and buffering hypotheses, Journal of Applied Social Psychology, 26, 686-716.

Yoon, J. \& Lim, J. (1999), Organizational support in the workplace: the case of Korean hospital employees, Human Relations, 52, 121-43.

Yoon, J. \& Thye, S. (2000), Supervisor support in the workplace: an empirical test of legitimation and positive affectivity, Journal of Social Psychology, 140, 295-316.

Yoon, J. \& Thye, S. (2002), A dual process model of organizational commitment: job satisfaction and organizational commitment, Work and Occupations, 29, 97-124. 